\title{
Theoretical Aspects of Public Goods Guardianship
}

\author{
Gotsulyak I.F. \\ Ignatjeva O.A.
}

Kazan Federal University, Institute of Management, Economics and Finance, Kazan, 420008, Russia

Email address: lenar_s@mail.ru

\section{Doi:10.5901/mjss.2014.v5n24p341}

\section{Abstract}

Following text describes theoretical aspects of public goods reproduction in terms of modern challenges from the prospect of government and private cooperation. Based on the analysis of the relationship of the public sector with public goods, text presents the discussion about creating evidence-based basis for constructing a system of public policy priorities. The concept of fiscal policy reviewed a set of basic goals, objectives, priorities and methods of financial management, constituent methodology of financial security concept of economic policy of the state (municipalities). The main priorities of fiscal policy development analyzed based on the goals, objectives and priorities for economic and social policy of the public authorities. Text is of general interest to those involved in the study of a mixed economy and social policy in the field of welfare states.

Keywords: public goods; public guardianship; economic theory; macroeconomics; public finance.

\section{Public Goods Reproduction in the Prospect of Government and Private Cooperation}

In recent years, public goods production and provision become a matter of particular relevance. The main objective of government public finance policy was the organization of the adequate revenue sources for such reproduction. Only under these conditions, it is possible to talk about the Pareto-efficient allocation of public benefits. From this position, we should talk about the process of production and distribution of public goods and the emergence in connection with this public commitment. Accordingly, the public goods are the specific group of goods and services, uniform production and distribution of which is associated with the emergence of public lawful obligations.

A specific feature of these goods and services group is contrary to the fundamental theorems of welfare, when trying to market their distribution [1]. When you select the competition and excludability parameters, inevitably arises a situation in which the benefit becomes non-competitive and non-excludable. That is - on the one hand - inability to give up its consumption, and - on the other - impracticality of production in terms of a market economy. So the question of the public guardianship organization over these goods raises. From the point of view of contemporary reality, in our view, it would be more correct to use the term "public guardianship", as it relates to public lawful obligations and public law entities.

With regard to Russia, the public law organization defined as an integral part of public law entities, which is involved in the production and provision of public goods, based on accepted public lawful obligations. As the practice shows, the adoption of specific decisions in the diversity of the public goods production and distribution management instruments reduced to a uniform set of some techniques, forming a definite financial policy.

Should note, that the public finances, expressed through the institution of public law entities play an important role in the financial system as a whole. Thus, we proceed to consider the role of public finance in the process of forming the financial sources of social reproduction. In other words, we express the importance of public finance in terms of two components: the part of public finances in the process of production and distribution of public goods and the provision of access to data benefits for everyone. The role of public finance, as part of the financial system, participating in the distribution of financial resources to the production and distribution of public goods, to a large extent determined by the legal component.

Institutional framework, through which fiscal policy implements, is a system of public law organizations. Public law organizations considered as a set of public authorities and all levels of government, non-market non-profit organizations, financed and controlled by the state (schools, hospitals, cultural institutions, etc.) and state funds - the primary function of which is the implementation of welfare state programs.

General government unites units carrying out the functions of government as the main activity. Functions of 
government are as follows: firstly - taking responsibility for ensuring that the company products and services on a nonmarket basis for their collective or individual consumption; secondly - the redistribution of the income and wealth by means of transfers and subsidies [2,3].

Government units operate within funding from the budget, extra-budgetary funds, borrowing, as well as from the proceeds of property sales and market services. The totality of public law organizations represented in the following organizational chart (Figure 1).

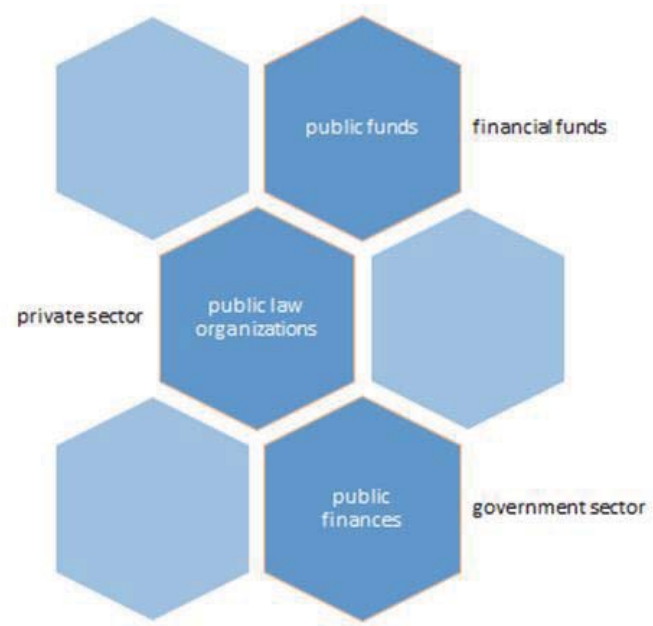

Fig. 1. Place of public law organizations in the Public Sector

Touching upon the issue of financial policies should immediately note features of public finances. Objectives of government (municipal) policies are the basis for the development of its priorities. Conventionally, the objectives divided into various segments in which these objectives will form. Thus, in the area of revenue targets due to the functions of the system of public revenues: fiscal and regulatory [4]. The main objective of fiscal policy expressed in full providing income sources of the production process of public goods.

This means that should be achieved parity in providing income sources planned expenditures, on the other hand - all collected revenues should direct to the performance of public obligations of the public authorities, as it is in the process of spending made the provision of public goods. Thus, the concept of the proposed financial policies included the concept is not public, and public finance [5,6]. At the same time, it does not reveal the features of the management of public finances. To expand the understanding of the financial management policies of public finances, consider the goals of the state (municipal) financial policies

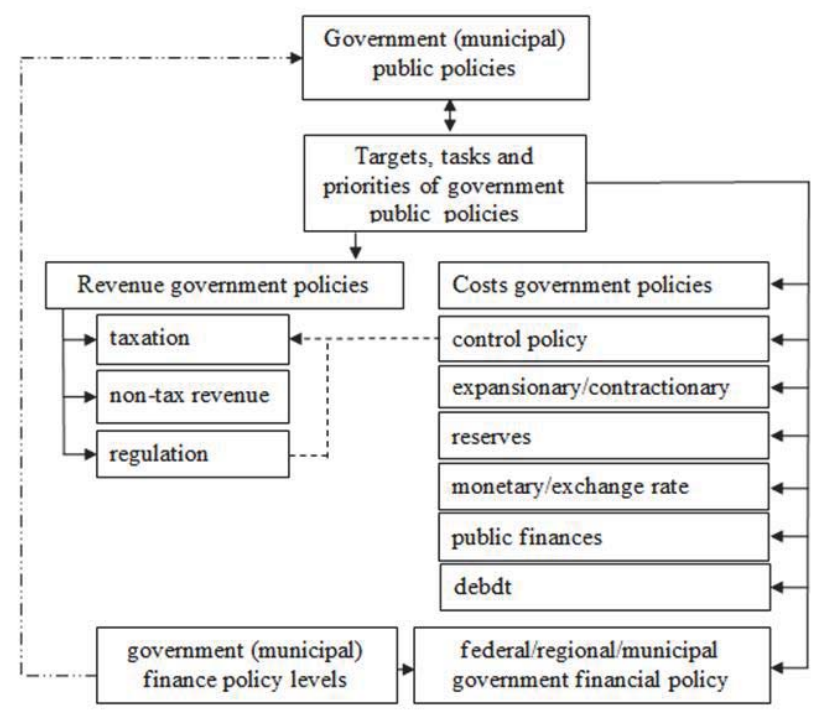

Fig. 2. The structure of the state (municipal) financial policy 


\section{Introduction of Public Guardianship}

The overall objective of the public guardianship is to create conditions for uniform production, distribution and consumption of goods. The main purpose of financial regulation is to minimize the social costs of guardianship to achieve its objectives. Hence, we allocate the total costs of social care, which are in the cost of maintaining a uniform demand, supply and consumption of goods. Then it becomes obvious source of counter-cyclical policy.

Relatively modern features of most types of wards benefits observed their approach through market instruments and government. As an example, partial solution to the "free rider" problem public goods [7]. These decisions include:

a) securing by contracts;

b) introduction of privileged groups;

c) "free riders" merge;

d) introduction of an exclusion mechanism;

e) introduction of social standards.

In addition, to illustrate the relationship of public goods to the distribution process of financial resources we have proposed an approach based on the findings of the study, grouped in the form of a generalized approach to public care [2]. This approach formulated in the form of Table 1.

Table 1. Classification of public (social) benefits

\begin{tabular}{|l|l|l|}
\hline Public goods & Problems & Solutions \\
\hline With standard market errors & $\begin{array}{l}\text { price uncertainty, the standard errors of the } \\
\text { market }\end{array}$ & hedging reserve in case of value deviation \\
\hline Baumol goods & "price disease" & price equalization \\
\hline Public property & non-excludable property & guarantee of production and uniform distribution \\
\hline Meritorical goods & $\begin{array}{l}\text { decline in demand, based on the lack of } \\
\text { information, the will and resources within } \\
\text { universal needs }\end{array}$ & stimulate the production / distribution \\
\hline
\end{tabular}

Based on the analysis of the relationship of the public sector with public goods, we can talk about evidence-based basis for constructing a system of public policy priorities. As we know, the concept of fiscal policy is a set of basic goals, objectives, priorities and methods of financial management, constituent methodology of financial security concept of economic policy of the state (municipalities) $[7,8,9]$. The main priorities of fiscal policy develop based on the goals, objectives and priorities for economic and social policy of the public authorities.

As the most important goals of modern government financial policies, the majority of domestic economists allocate development and implementation of an effective system of full financial support and financial incentives accelerate sustained economic growth in the country, allowing a relatively short time to become leaders in the global economic environment and the well-being of citizens. As evidence of the realization of this goal, lead GDP growth.

In our view, this approach, at least, is debatable. Due to the fact, that the regulatory definition of efficiency is not fixed and is not offered, usefulness of indicators of financial security doubtable and it is impossible to talk about the implementation of these financial policy objective parts. At the same time, the size of GDP cannot characterize stability and economic growth, because economy cyclical nature causes periodic changes in its volume.

Talking about the release dates in the leading countries, we should specify the planning horizon, as the phrase "in a relatively short period of time" does not provide a basis for predicting positive change [10]. In accordance with the theory of well-being, of course, can be regarded as the purpose of improving the welfare of citizens' financial policy, but in the part of the public sector and the public goods provided by the state, as we have previously shown, there is a contradiction of their distribution process with the theory of well-being. In connection with this, in our opinion, one should not talk about improving the welfare of citizens, as the purpose of government financial policy. In terms of fiscal policy, we should rely on two fundamental factors: the reality and attainable - and operate within the framework of these definitions, performance criteria, and the uniqueness of the specific.

Under the attainable hereafter, we mean a fundamental criterion of completeness fulfill the objective, in other words, the goal should be achievable within the planning horizon. Reality goal implies that it has a scientific and legal basis that would allow us to speak of its concreteness. Defining the purpose of financial policy indicates its viability and relevance: that is, the unbiased forecast estimates and results.

Addressing to the main objective of financial policy, we should ensure that full spectrum of the public goods 
production and distribution revenue sources present. From this point of view, Richard Abel Musgrave notes that the main functions of government financial policy should include $[5,6]$ :

1. Ensuring provision of public goods, or process in which the total resources divide between the production of private and public goods, and defines a set of alleged public goods. Providing public goods expresses the distribution function of fiscal policy.

2. Adjustment of the existing distribution of income and wealth in order to ensure compliance with public notions of equitable distribution - redistributive function.

3. Use of fiscal policy as a means of ensuring high employment, a reasonable level of prices and the corresponding level of economic growth, taking into account effects on trade and payments balances stabilization function.

4. The basis for goal setting government financial policy are listed functions in the annex to the emerging economic problems.

Linking medium-term priorities of government financial policy with the basic functions of the public sector, and knowing the characteristics of the relationships between various financial flows, it is possible to build a state financial policy based on the principles of the system, the efficiency and rationality. Based on the production function, we can talk about arrayed state policy in the field of public goods. As part of the construction of the policy should be aware that when we are talking about ensuring the production of a public good, the state, we mean that the budget finance them. It does not matter who produced public goods: a private organization or a government.

Applying this scheme to our case, we can say: firstly - the volume of direct public procurement plays a more important role in the creation of public goods; secondly - the volume of public procurement and private equity-related values can be represented in the form of indifference curves [11,12].

Thus, in each case, the choice between investing in the creation of wealth and the organization of the state order, to be considered a scenario as a set of equivalent goods and the start of the budget constraint [13].

Applied to our model, we should note the identified trends:

a) the higher level of well-being leads to the higher share of the private sector in the production and distribution of public goods;

b) the greater unevenness of public law entities leads to the lower efficiency of the private sector in the distribution of public goods;

c) the amount of the returned funds through taxation leads to the value of maximum decreases, which leads to its low impact on the amount of running public obligations;

d) direct transfers (monetized benefits) leads to less benefits.

Thus, based on the identified dependencies, there is the possibility of the flexible process control of the distribution.

\section{Summary}

In summary, we can put forward specific proposals for the formulation of priorities for government financial policy:

1. Should be to discourage the demand. This is due to the fact that, because of the preferences of direct investment, there was no increase of production of goods; the assumption that a high enough effective demand will automatically trigger the growth of production is unfounded, because of the propensity to import substitution;

2. We need to create an effective mechanism for the organization of public procurement: give control functions in the field of quality of public works contracts, increase the volume of orders, stimulate the production of public goods with the help of government contracts;

3. On a par with that, the choice between public order and investments should be considered from the perspective of the process of hidden costs;

4. It is necessary to concentrate on the more backward regions, due to the fact that under the condition of growth of wealth due to the unevenness of access to public goods distribution efficiency will fall;

5. The need to reduce the costs associated with governance.

Thus, we believe that the priorities of state policy formulate in the form of three main areas: increased productivity, lower costs for state governance and alignment of the level of economic development of the regions. As part of each direction are the following solutions: a high salary to replace officials social package, align wages, replacing surplus wages a large range of benefits (including for utilities and taxation). Therefore, the change in inequality between the private and public sector. Based on estimates of the solution of direct investment or PPL will be possible to support a proposal to temporarily unclaimed goods, providing demand for the products of mono-towns. Finally, tax-efficient (up to 
negative tax rates) for organizations operating (placing manufacture) in backward regions.

\section{References}

Alam P. and K.S. Walton. Information Asymmetry and Valuation Effects of Debt Financing. The Financial Review, 2005

Baumol W.J., Bowen W.G. Performing Arts: The Economic Dilemma. New York, 1966.

Calculation of the net asset value (NAV) for the investment funds. Term paper. Module: European investment funds: regulation, innovation, management. Kuljich Behair, 2007

Miller, M.H. and K. Rock. Dividend Policy Under Asymmetric Information. The Journal of Finance, Reprint, 2007.

Musgrave R.A. Merit Goods. In: The New Palgrave / J. Eatwell, M. Milgate, P. Newman (Hrsg.). London1Basingstoke, 1987

Musgrave R.A. The Theory of Public Finance. N.Y., 1959.

Nissen, M.E., A Multi-Agent Approach to Supply Chain Disintermediation, Proceedings of the 9th Annual Workshop on Information Technologies and Systems, 1999.

Presented at 8th DNB Research Conference "Pensions in an Ageing Society," November 11, 2005. Dirk Broeders, Jeremy Gold, Jared Gross, Deborah Lucas, Robert C. Merton, Theo Nijman, and Jonathan Treussard.

Public Administration: Challenges of Inequality and Exclusion Miami (USA), 14-18 September 2003 International Review of Business Research Papers

Warkentin M., R. Bapna, V. Sugumaran The role of mass customization in enhancing supply chain relationships in B2C e-commerce markets, Journal of Electronic Commerce Research, Vol. 1, № 2, 2000.

Kundukchyan R.M. Performance Evaluation of Institutional Integration Forms in Real and Financial Sector Companies / R.M. Kundukchyan, R.R. Gaizatullin, Z.N. Zapparova, N.V.Antonova // Mediterranean Journal of Social Sciences. Vol. 5, № 12 (2014). 0,8 п.л. (авт. - 0,25 п.л.). http://www.mcser.org/journal/index.php/mjss/article/view/3026/2986.

Kundukchyan R.M. Development of Integration Relations Involving Russian Real and Financial Sector Entities/ R.M. Kundukchyan, R.R. Gaizatullin, Z.N. Zapparova, N.V. Antonova//Mediterranean Journal of Social Sciences. Vol. 5, № 12 (2014). 0,8 п.л. (авт. - 0,25 п.л.). http://wwww.mcser.org/journal/index.php/mjss/article/view/3028/2988

Kundakchyan R.M., Zulfakarova L.F. Current issues of optimal capital structure based on forecasting financial performance of the company / Life Science Journal 2014; 11(6s). p. 368-371. http://www.lifesciencesite.com/lsj/life1106s/075_24315life1106s14_ 368_371.pdf 